\section{Public Health Genomics}

Public Health Genomics 2018;21:1-17

DOI: $10.1159 / 000492809$
Received: August 8, 2018

Accepted: August 13, 2018

Published online: August 24, 2018

\title{
Optimising SME Potential in Modern Healthcare Systems: Challenges, Opportunities and Policy Recommendations
}

\author{
Denis Horgan $^{a, b}$ Henk J. van Kranen ${ }^{b, c}$ Servaas A. Morréb, d

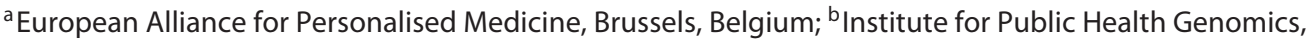 \\ Department of Genetics and Cell Biology, Research Institute GROW, Faculty of Health, Medicine and Life Sciences,

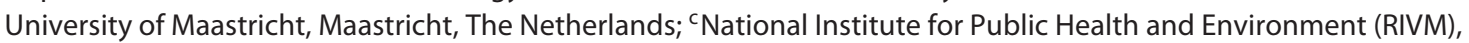

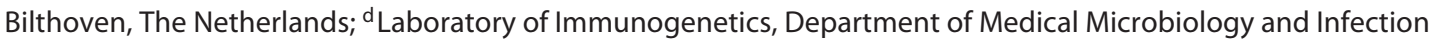 \\ Control, VU University Medical Center, Amsterdam, The Netherlands
}

\author{
Keywords \\ Small and medium-sized enterprises (SMEs) · Big data . \\ Regulation · Finance - Scaling up - Unicorn · Innovation . \\ Commission · European Union
}

\begin{abstract}
The expansion of European small and medium-sized enterprises (SMEs) into the healthcare innovation arena suggests that this should be an important EU policy priority that can significantly benefit the economy, society and citizens, including patients. Deepening and widening of Europe's SMEs' growth and activities is part of the EU objectives as set out by the European Commission in its Communications "Small Business Act" for Europe [1] and "Small Business, Big World" [2]. However, innovative healthcare SMEs have struggled to get traction despite the sector being worth more than EUR 250 billion. The 1991 Maastricht Treaty gave the Union new competences in public health and more scope for cross-border cooperation in this area [3]. Nevertheless, health initiatives here have tripped over each other, due to the fact that the delivery of healthcare is a national competence [4]. As
\end{abstract}

such, EU healthcare-driven policy has never truly found its footing as a singular policy area despite the fact that a tenth of the EU's GDP is spent on healthcare and more than 17 million people are employed in Europe in this sector [5]. Taking into account the necessity of bringing innovation into healthcare, and the willingness of SMEs to undertake the risk to be at the forefront of it, there is a need for a renewed effort to support SMEs so as to provide solutions for citizens and patients throughout the bloc in different healthcare settings [6]. This policy paper brings together two separate strands of analysis: firstly, a policy review of the main challenges and opportunities; secondly, a proposal for policy recommendations.

c) 2018 S. Karger AG, Basel

\section{Introduction}

In all the talk about EU innovation, one crucial area is often overlooked in the policy arena for health and care systems - and that is the role of small and medium-sized enterprises (SMEs) [7]. For our purposes, the term "health

\section{KARGER}

(C) 2018 S. Karger AG, Basel 
and care systems" implies a broader notion than "health systems" or "healthcare systems," notably encompassing public health and social care [8]. SMEs operate mainly at Member State level, as relatively few engage in cross-border business within the EU [9]. Independently of their operational activities, SMEs are increasingly affected by EU legislation in various fields, such as taxation (Articles 110-113 of the Treaty on the Functioning of the European Union [TFEU]), competition (Articles 101-109 of the TFEU) and company law (right of establishment Articles 49-54 of the TFEU) [10].

The Commission's definition of SMEs can be found in Recommendation 2003/361/EC [11]. The main factors determining whether an enterprise is an SME [12] are:

1. Staff headcount

2. Either turnover or balance sheet total (see Box below)

\begin{tabular}{|llll|}
\hline $\begin{array}{l}\text { Company } \\
\text { category }\end{array}$ & $\begin{array}{l}\text { Staff } \\
\text { headcount }\end{array}$ & Turnover or & $\begin{array}{l}\text { Balance sheet } \\
\text { total }\end{array}$ \\
\hline $\begin{array}{l}\text { Medium-sized } \\
\text { Small }\end{array}$ & $<250$ & $\leq$ EUR $50 \mathrm{~m}$ & $\leq$ EUR $43 \mathrm{~m}$ \\
Micro & $<10$ & $\leq$ EUR $10 \mathrm{~m}$ & $\leq$ EUR $10 \mathrm{~m}$ \\
& $<$ EUR $2 \mathrm{~m}$ & $\leq$ EUR $2 \mathrm{~m}$ \\
\hline
\end{tabular}

The 7th Framework Programme for research and technological development (FP7) pays special attention to SMEs through its different programmes: "Co-operation" (circa EUR 32.3 billion), "Ideas" (circa EUR 7.5 billion), "People" (circa EUR 4.7 billion) and "Capacities" (circa EUR 4 billion) [13].

The healthcare sector encompasses several categories of interest to present and future SMEs deciding whether to enter the healthcare services and product market. This includes medical equipment, instruments and services as well as biotechnology, diagnostic laboratories and substances, primary prevention sensors (i.e. wearable health systems based on wireless body sensor networks) plus medicine development and delivery. With respect to innovative medical devices in the personalised medicine era, the possibilities are huge in diagnosis, therapy and business e.g. from diagnostics, therapy, companion diagnostics and monitoring to commodities suitable to more general healthcare provision.

People, as well as new technology, drive innovation. Europe needs a new mindset, and quickly. In a $2017 \mathrm{Eu}-$ robarometer poll that addressed topics such as the European political situation, the economy and European citizenship, health is mentioned by $23 \%$ of Europeans, in second place behind unemployment, and in first place in nine EU Member States (up from eight in autumn 2017), with the highest scores in the Netherlands (49\%), Sweden (48\%) and Finland (47\%) [14]. According to a Eurobarometer poll that focused on the added value of EU actions, when it comes to health and social security, $70 \%$ of people would like the EU to intervene more, while $49 \%$ feel current EU action is insufficient [15]. Accordingly, there is a growing chorus from EU citizens that the EU should develop and support interventions to tackle the health challenge so that solutions can be developed for today's future diseases to ensure delivery of healthcare services [16].

The burgeoning ageing population means that treating diseases of elderly people has unique challenges that cannot be overcome solely by increasing healthcare budgets [17].

While positive signs have emerged, the EU has not yet overcome the effects of the 2008 economic crisis. Although the Commission's political agenda has focused on strengthening EU competitiveness, by stimulating public and private investment, there needs to be an increased focus on SMEs in the healthcare arena, who can adapt more quickly than multinational companies, understand the local context and be understood by the local administration, and fill the gaps and opportunities [18]. Of course, there are challenges, and these should not be underestimated. The variety of SMEs in the EU is considerable. Different Member States and regions have different types of SMEs, depending on the business model, size, stage of evolution, financial structure and legal form [19].

Furthermore, country-specific factors including the economic environment, structural factors such as the legal framework, and cultural norms have a strong influence on success and failure. All of this affects the productivity, profitability and risk profile of SMEs [20]. This heterogeneity also means a high complexity of SME financing and regulatory hurdles [21]. Given these labyrinthine factors, it is difficult to find a single solution. This is reflected in the varied policy measures that have being developed and are discussed below.

Above all factors, access to funding is a key enabler [22]. A recent study estimates that a $1 \%$ increase in $R \& D$ spending can grow the economy by $0.61 \%$ [23]. Whilst innovation constantly re-shapes the global economy, new markets emerge - as illustrated by the eco-innovation market, for instance, which amounts to EUR 225 billion [24]. By correlation, investment in SMEs in the healthcare arena can have the same impact with the development of innovative healthcare services and products that will impact on citizens' quality of life [25]. Taking this into account, a recent announcement by the Commission is 
encouraging, with the EU considering a EUR 9.2 billion budget to boost tech innovation over the next decade [26].

This policy message was reaffirmed tangibly, with a recent loan announced on 27 July 2018, providing finances for research and development to SMEs for innovative cancer treatments [27]. This loan agreement came following the confirmation that the Juncker Plan's European Fund for Strategic Investments (EFSI) has mobilised EUR 335 billion in additional investment since July 2015, exceeding the initial target of EUR 315 billion [28].

Therefore, the EUR 9.2 billion proposed budget to boost the EU's technology and health innovation economy, which is complemented by the regulatory efforts to transform the healthcare arena with the revision of the GDPR (General Data Protection Regulation), provides the correct signals for SMEs considering entering the healthcare market [29]. The Commission's hope is that such fiscal stimuli could tackle Europe's innovation deficit and, at the same time, ensure that "European citizens will stay at the heart of this programme" (European Commissioner for Digital Economy and Society Mariya Gabriel) [30].

This policy paper addresses five dimensions which encompass barriers and enablers, heterogeneity and regional diversity, small enterprises in large EU frameworks, EU policy frameworks, and proposed policy recommendations. It discusses the underlying factors which create challenges to SMEs trying to capitalise on opportunities in the healthcare sphere. We group these factors into policy/regulatory and investment factors. After the discussion of the factors, the policy paper provides a number of recommendations. The paper has the goal of giving policy makers and researchers an overview of challenges and opportunities and provides avenues for uptake and refining of policy.

\section{SMEs in Numbers and Barriers}

There were more than 22.3 million SMEs operating in a range of sectors including healthcare in the EU in 2015, employing some 90 million people, across the bloc [31]. These enterprises generated around $58 \%$ of the total added value (EUR 3.9 trillion), created some $85 \%$ of new jobs and around two-thirds of total private sector employment [32]. After declining for a number of years following the 2008/2009 economic and financial crisis, EU-28 SME employment has picked up and outshone the economy as a whole [33].

Optimising SME Potential in Modern

Healthcare Systems
EU-28 SME employment grew by 5.2\% from 2013 to 2016, almost 50\% faster than overall employment over the same period [34]. There are many areas in which SMEs can and do have a major role to play, not least that of personal healthcare, including personalised medicine. One-tenth of the EU's GDP is spent on healthcare and the sector employs roughly 15 million people [35].

Healthcare is a unique area for innovation, and often health means wealth - whether that be driving economic growth and creating jobs or reducing costs across increasingly cash-strapped healthcare systems dealing with ageing populations and the attendant increases in co-morbidities and chronic diseases [36]. Furthermore, $110 \mathrm{Eu}-$ ropean regions have identified active and healthy ageing as a smart specialisation priority [37]. SMEs have a major part to play, but there need to be tailored initiatives to support them for cross-border enterprise, at EU level and internationally, such as procurement initiatives which will increase incentives for the EU's trading partners to open up their public procurement markets [38].

Until recently, SMEs that have emerged have not been scaling up to become major employers and market leaders, which has been equated to a EUR 1 billion evaluation [39]. This is demonstrated by the number of young companies that have reached a market valuation of over EUR 1 billion, with the EU home to 19 unicorns (e.g. BlaBlaCar, Rocket Internet and TransferWise), compared to over 100 in the USA (e.g. Facebook, Google and Amazon) [40].

Additionally, European unicorns are smaller - their combined value comes in at less than half the current market value of Facebook [41]. According to the 2016 start-up and scale-up public consultation, securing finance for expansion is the main obstacle to start-ups' growth, followed closely by obstacles related to regulations [42]. Other areas include a business environment that is receptive to SMEs, technology diffusion, management capabilities and access to existing and future markets. These factors will ensure that SMEs can stay innovative and flexible to adapt to market conditions in the interim if they do reach the heights of transitioning from an SME to a multi-national company and/or developing spin-off SMEs that can take on this innovative role.

However, as a result, there are glimmers of a silver lining for SMEs. This year has seen a series of billion-dollar European companies which have staged successful IPOs. Since January 2018, 27 IPOs totalling USD 32.5 billion have been launched in Europe, eclipsing the 57 listings worth USD 8.28 billion last year [43]. This includes Spotify, a Swedish music streaming company, listing in April with a share offering valued at USD 29 billion; Avast, a

Public Health Genomics 2018;21:1-17 
Czech cybersecurity group, with a valuation of USD 2.7 billion; and another Swedish SME, iZettle, focused on digital payment, with an offer of USD 2.2 billion [44]. While these IPOs provide hope, it is clearly of vital importance that research and innovation-based SMEs should be prioritised in Member State and EU budgets. Because despite all of Europe's quality innovation, wonderful research and great science, the EU performance gap with respect to Japan and South Korea is expected to increase, and the performance lead over China is expected to decrease [45]. While existing EU, Member State and regional systems were designed and developed to support innovation and access for patients to innovative medicines and treatment, these systems are falling short and need to be reassessed [46].

Essentially, and demonstrably, Europe has been slow in adopting emerging health technologies into its healthcare systems [47]. When looking ahead to the future of Europe in a globalised world or a Trump de-globalised world, the contrast is striking between Europe's comparative advantage in producing knowledge and its comparative disadvantage in turning it into innovation and growth [48].

The rate of health technological and economic change and the urgency of global challenges continue to outpace Europe's response and reforms [49]. The key innovators need support to succeed, and this includes SMEs.

Figures have revealed that fewer than 5\% of European SMEs conduct cross-border business in the EU [50]. This can be down to any of several aspects: national and regional legislation, $\mathrm{EU}$ legislation (including taxation and financing rules), law (common and civil law) and competition, among others [51]. And it is a startling fact that, each year, some 200,000 SMEs go bankrupt, which required the EU to develop a new approach on business failure and insolvency [52].

During the financial crisis, and specifically from 2008 to 2014, some 20 Member States reported net employment reductions among SMEs, and 8 said that these losses were double-digit [53].

A survey of 12 National Industry Associations (including all the major medical technology exporters) across Europe identified almost 7,000 SMEs that design and manufacture medical devices and diagnostic products. These companies face significant barriers that prevent them from reaching their potential. Specifically, the Commission has found that SMEs have difficulty with product registration, reimbursement, procurement, distribution channels, health technology assessment and access to R\&D incentives [54].

\section{The EU Is at a Tipping Point: Heterogeneity and Regional Diversity}

With $6.9 \%$ of the world's population and $24 \%$ of the global GDP, the EU suffers from a growth and SME success deficit compared to other economies [55]. Europe has not capitalised enough on the knowledge it has and produces. The European economic structure is mainly based on SMEs as a motor of Europe's economy [56].

As stated, the EU's SME landscape is not homogeneous. SMEs are a heterogeneous group. Despite internal market rules, important divergences across the EU persist in terms of the SME regulatory framework, in particular regarding its stability and certainty level [57].

While in stable economies, growth is generated on the basis of efficient interaction between SMEs and big companies, in many southern and eastern Member States, difficult economic circumstances have stifling effects on SMEs' development [58]. Moreover, in the economies focused on attracting foreign investment, business representatives report discriminatory attitudes towards micro and small enterprises from public authorities, in particular at fiscal and judicial levels [59].

SME representative organisations and networks are generally less developed in new Member States and their position vis-à-vis the national administration and financial institutions is weak [60]. A lack of macroeconomic stability, as well as of predictable and transparent regulations, results in the fact that SMEs in many post-2004 enlargement and Eurozone crisis countries suffer from unfavourable development conditions [61].

\section{Issues Arising: Small Enterprises in a Large Europe}

\section{Financing SMEs: Mind the Gap}

Many SMEs have failed by overextending themselves across multiple EU markets. Sometimes, they miss opportunities to leverage local funding sources to augment commercialisation [62]. The reliance of SMEs on bank lending and the deleveraging of banks triggered by the economic crisis have contributed to their failure [63]. Access to financing for SMEs was restricted compared to larger companies during that time [64].

Accordingly, the Capital Markets Union (CMU) initiative, which is to be completed by 2019 , made the diversification of and access to funding options for SMEs one of its main priorities [65]. Bank lending still constitutes the most important source of funding for SMEs. Lending to an SME is often built on a long-term relationship [66]. 
Banks with regional and local knowledge can adapt to the specific funding needs of the diverse SMEs in the best way. Banks have expertise in assessing the credit risk and can build their assessment on the credit history [67]. Therefore, there is a need to underline that addressing and fostering the bank lending channel is the most effective way to ensure and improve access to finance for SMEs in the health innovation arena [68].

\section{Filling the Gap: Non-Profit Activities and SMEs}

to the Rescue

Gaps in public health services have often been filled by non-profit organisations and charities [69]. Despite the existence of healthcare systems, non-profit organisations such as in the area of cancer have propped up care for decades, plugging gaps in home care, travel costs, research funding and palliative care, as well as helping patients navigate the complexities of the health system itself [70]. Furthermore, non-profit patient organisations in the rare disease area have been financially supporting work led by medical professionals and donating specimens required for undertaking such work, as well as shaping research agendas [71], study designs to reflect their own perspectives and the development of orphan drugs. In one case, this resulted in founding a start-up company to develop a promising line of treatment, in another in the initiation of clinical trials of a drug that has shown some evidence of efficacy [72].

The reliance on charities and use of crowdfunding represent failures in publicly funded healthcare systems [73]. Crowdfunding is an alternative channel for financing a project that uses an online platform to solicit generally small contributions from numerous participants [74]. While crowdfunding and non-profit organisations can support the healthcare system, there needs to be improved integration with SMEs to spur innovation, which in turn will ensure efficient hospital discharge, outpatient management, and long-term care [75].

\section{Certainty and Collaborative Framework}

There are potential public and private funding opportunities that are often available, although there are risks and benefits in pursuing them [76]. In healthcare, the long-term plans of many SMEs include either collaboration with or acquisition by pharmaceutical or large device companies. Successfully identifying a pharmaceutical partner can transform a company and allow it to achieve its corporate objectives faster [77].

On the other hand, many partnerships can end poorly if there is a lack of alignment on objectives. SMEs should balance the trade-offs. Meanwhile, many new products are being introduced which do not clearly fit the current regulatory framework, so a dialogue with the right regulatory agencies can accelerate the time to market. Companies need to consider not only current regulations but also future regulations going to be initiated in the next 5 years or so [78]. Public-private partnerships are seen as growing driving forces in the quest for the development of innovative healthcare both in the USA and the EU. Through the Innovative Medicine Initiative in the EU and the Critical Path Initiative in the USA, they have facilitated the emergence of innovative medicines by developing new tools for drug discovery, new indicators for drug efficacy or safety, and new approaches to patient stratification [79].

\section{Market Authorisation and Regulatory Pathways}

SME executives need to pay close attention to regulations that go beyond marketing authorisation and consider topics such as national and EU data privacy laws. Yet, in contrast to regulatory processes which mostly happen at EU level, harmonisation of reimbursement pathways across Europe is limited [80].

This situation can be challenging for large pharmaceutical companies but can be devastating for small companies unable to generate the revenue to support commercial activities. Not understanding legislative changes can severely hamper SMEs, which end up wasting time and resources [81].

Take Health Technology Assessment agencies. While they are attempting to coordinate their review processes, these efforts are at a preliminary stage, and most companies need to engage with each reimbursement agency [82]. Engaging each local authority can be particularly challenging especially for diagnostic and digital health companies, where defined pathways often do not exist. While the task of gaining reimbursement can seem daunting, companies can often engage some local reimbursement agencies in advance to gain feedback on evidence requirements [83].

Also, there are many bridging programmes available which can help companies in accessing funding ahead of reimbursement. In the modern EU, each healthcare market is configured to meet the needs of each country's interest and that of its citizens [84].

Therefore, SMEs marketing products in Estonia, Germany or Greece, for example, need to adapt their approaches to each individual local market. SMEs are often forced to prioritise markets and tend to focus their efforts on the "Big Five" (Germany, France, UK, Italy and Spain) 
[85]. Other considerations for companies are whether they should commercialise their products directly or through a distributor. Additionally, there are products such as complex diagnostics or gene therapy products that require centralised processing, and the location of these facilities can lead to downstream issues [86].

On top of this, some companies are leveraging technology to provide centralised solutions that are delivered locally. Unfortunately, some SME healthcare executives lack the context to conceptualise which questions should be asked in new markets. There are a range of topics that may be unanticipated when commercialising a pharmaceutical or diagnostic. Being exposed to new topics could open the door to opportunities or could help avoid costly missteps. The topics may be related to conducting clinical trials, interacting with patients or building the right team.

\section{MEGA - Genomes as a Driver of Innovation}

One upcoming initiative that may help to involve SMEs involves transparency and the greater sharing of data - the MEGA project (Million European Genomes Alliance). In April, at the European Commission's Digital Day 2018, 16 countries signed a Joint Declaration to collaborate on a groundbreaking 1-million genomes project. In front of high-level stakeholders in the fields of digital technology and telecommunication, representatives of the Member States co-signed the Declaration indicating political support for linking existing and future genomic databanks [87].

This will work on a voluntary basis with the goal of making a cohort of 1 million sequenced genomes accessible in the EU by 2022, linking genetics across borders.

It will involve the collection of large amounts of "healthy" and "diseased" genomes in a similar way to the 100,000 Genomes Project in the UK, and former President Obama's Precision Medicine Initiative in the USA. The Declaration was and is a watershed moment for European health research and clinical practice: sharing more genomic data that complement other health data sets will improve understanding and prevention of disease, allowing for more personalised treatments (including targeted drug prescription).

The countries which signed the declaration are the Czech Republic, Cyprus, Estonia, Finland, Italy, Lithuania, Luxembourg, Malta, Portugal, Slovenia, Spain, Sweden, the UK, Bulgaria, Croatia and Greece, and there is ongoing interest from other countries (France) and regions (North Rhine-Westphalia in Germany).
The signatory Member States commit to collaborating on secure and authorised access to national and regional banks of genetic data and other data relevant to health.

This alliance has the potential to form a unique data resource (due to the heterogeneity of populations) by leveraging and maximising the investments already made by Member States at national and EU level, particularly in sequencing, biobanking and data infrastructure.

There is a commitment to develop policies that "define a governance model of the cooperation, particularly concerning the terms and conditions for distributed access to genomic data across-borders, usage of the data and others."

MEGA will support a mechanism for optimal public/ private cooperation around the sharing of health data [88]. It is in line with the European Commission's Digital Single Market mid-term review priorities, including the goal of "supporting the establishment of a secure health data infrastructure at EU level, to advance research and personalised medicine" [89]. Furthermore, the declaration is pursuant to the Commission Communication of 25 April 2018 including, inter alia, "supporting data infrastructure, to advance research, disease prevention and personalised health and care in key areas including rare, infectious and complex diseases" [90].

An initiative as challenging and complex as MEGA requires a truly collaborative approach to catalyse health improvement, research advances, commercial success, and public engagement with genomics, research and their own health [91]. Although the public sector will be fundamental for health, academia for research, companies for commercial success, and policy makers and the third sector for public engagement, all partners will contribute to success in each area [92]. This will, of course, include SMEs.

From the cancer perspective, existing views like those of the EAPM White Papers on lung cancer [93], melanoma [94] and pancreatic cancer [95] in Europe (but also lessons learned from the Cancer Moonshot initiative in the USA and others) could be used as real-life examples.

\section{EU Policy: Evolution, Not Revolution}

\section{EU in Action}

Since 2011, a number of EU measures have been adopted that will support the development of a personalised medicine policy framework as well as SMEs entering the area. These include

- the Clinical Trial Regulation, which will facilitate the conduct of clinical trials in the EU [96]; 
- the GDPR, which makes the legal framework in this area fit for the digital age [97]; and

- the in vitro diagnostic and medical device legislation, which aims to adapt EU legislation to technological and scientific progress [98].

The Directive on patients' rights in cross-border healthcare [99] established the eHealth Network to advance the interoperability of eHealth solutions. Cooperation structures have also been developed; for example, the European Innovation Partnership on Active and Healthy Ageing [100], the Active and Assisted Living Joint Programme [101] and public-private partnerships such as the Innovative Medicines Initiative [102].

Regional and national smart specialisation strategies also play a central role in the development of stronger regional ecosystems around the SME domain and healthcare professionals [103].

Since 2004, two eHealth Action Plans have provided a framework for policy action for the Member States and the Commission, and the eHealth Stakeholder Group has played an important role stimulating SMEs in the digital area [104].

Under the Luxembourg presidency of the EU (July to December 2015), European Health Ministers adopted Council conclusions on personalised medicine [105]. The Council conclusions from the Bulgarian presidency were endorsed by all Member States on 28 June 2018. The European Council confirmed the set-up of a European Innovation Council for market-creating innovation under the next long-term budget. The Council also invited the Commission to launch a pilot initiative on breakthrough innovation within the remaining time of Horizon 2020. The Bulgarian Council conclusions prioritise the need for "a stronger, inclusive innovation ecosystem to foster breakthrough and market-creating innovation and provide comprehensive support for businesses, including SMEs" [106].

Research infrastructures (RIs), as set out in the ESFRI (European Strategy Forum for Research Infrastructures) roadmap, provide an interdisciplinary, innovative environment in the field of life sciences and health research where world-leading investigators conduct pioneering research using open access to cutting-edge technologies and scientific data [107].

According to the EU, such RIs will play a key role in closely linking basic research to medical application, providing services, training and access to technology for scientists in academia as well as SMEs [108]. The Biobanking and Biomolecular Resources Research Infrastructure (BBMRI), the European Advanced Translational Re- search Infrastructure in Medicine (EATRIS) and the European Clinical Research Infrastructures Network (ECRIN) were awarded the ERIC (European Research Infrastructures Consortium) status [109].

These RIs throughout Europe are expected to strengthen the scientific competitiveness of SMEs, as well as to encourage them to enter the market, by producing accessible high-quality instruments and providing access to resources developed by European countries (healthcare databases, genetic databases, etc.) [110].

Such frameworks that encourage a climate of collaboration, sharing and exchange of knowledge can further strengthen the European position of developing an active SME industry in the healthcare arena.

Such policy initiatives are echoed at Member State level, such as those carried out by the UK Academy of Medical Sciences [111], the German Academy of Sciences Leopoldina [112], the German Personalized Medicine Action Plan [113] or the Genomic Medicine France 2025 plan [114].

Jean-Claude Juncker previously set out guidelines that include helping SMEs, mainly from the point of view of lowering regulatory and administrative burdens, making it easier and cheaper to raise capital, boosting investment in new technologies and bumping up skill sets [115].

The Berlaymont's European Fund for Strategic Investments, its single-market strategy and the emerging digital single market are theoretically geared, in part, to help Europe's SMEs. Other initiatives exist that would be able to help, including the late-2016 start-up and scale-up initiative, which is designed to break down barriers faced by start-ups trying to grow in the single market.

This, linked to increasing the financial literacy of SMEs, is therefore a prerequisite to creating a capital market culture with entrepreneurs willing to consider the use of capital market solutions [116].

\section{Markets outside the EU for SMEs}

Ninety percent of market growth over the next decade is expected to be outside Europe [117]. European SMEs need to gain more knowledge from international markets, participate in new value chains and reap greater benefits from these growing markets. Of course, different business approaches will need to be taken by these SMEs, such as debt and equity financing, with low- and middleincome countries. This would notably involve international cooperation on innovation activities such as largescale trials or demonstrations and would result in enhanced competitiveness [118]. 
The aim is to create better partnership opportunities, commercial opportunities and skill development while providing better access to finance. It is geared towards removing many of the problems faced by Europe's SMEs. Juncker's Commission is also seeking to avoid creating more regulatory barriers than already exist in innovation and other areas, and it has gone some way to addressing this through changes to Horizon 2020 [119]. This must continue into the next Commission, especially in the healthcare arena.

Meanwhile, the Commission strategy should help the EU's competitiveness by boosting start-ups, SMEs and companies that use data for research and development with innovation as a key goal.

\section{Digitising the European Industry}

In a recent 2017 European Commission Special Eurobarometer survey entitled "Citizens' Attitudes towards the Impact of Digitisation and Automation on Our Daily Lives," the survey indicated that two-thirds of Europeans think that the most recent digital technologies have a positive impact on society, the economy and their own lives. Furthermore, a majority of respondents were of the opinion from this survey that the EU, Member States' authorities and companies need to take action to address the issues raised around digitisation [120]. SMEs can develop needed actions to create digital solutions to these unmet health needs.

The data-driven economy policy has always been intended to benefit SMEs as part of its added value. As such, it is envisioned that digital innovation hubs will give SMEs better access to information and, indeed, even upto-the-minute testing facilities [121].

Cloud-based high-performance computing resources, applications and analytic tools should become more readily available too. Innovation hubs available for SMEs should become mainstream, allowing great opportunities for them to develop creatively innovative solutions. This year the Commission published a report on research and innovation performance in the EU [122].

Two specific areas in which the EU has developed policies that can propel SMEs in the area are:

- Open Science Cloud: deriving from the ongoing integration and consolidation effort supported under the "e-Infrastructures" priority of Horizon 2020, it aims to develop a trusted, open environment for the scientific community for storing, sharing and re-using scientific data and results [123]. This was stated in the Commission's "Communication: European Cloud Initiative Building a Competitive Data and Knowledge Econo- my in Europe" [124]. In October 2016, the High Level Expert Group's report on the European Open Science Cloud [125] comprised a number of recommendations to the Commission on a preparatory phase for the Cloud that included (1) designing appropriate incentives and developing common standards for data sharing, and promoting data literacy, (2) facilitating greater access to publicly funded scientific publications and (3) promoting "living labs" demonstration projects engaging all relevant stakeholders in action research activities demonstrating solutions to challenges

- Open Science Policy Platform: this will co-shape the policy. There are eight priority topics for action: Rewards, Altmetrics, Open Science Cloud, The Future of Scholarly Publishing, Research Integrity, Citizen Science, Open Education and Skills, and FAIR Open Data. The Council conclusions of May 2016 underlined that: "[o]pen access to scientific publications and optimal reuse of research data are of utmost importance for the development of open science. The Council agrees to further promote the mainstreaming of open access to scientific publications by continuing to support a transition to immediate open access as the default by 2020" [126]

Personalised medicine, with its use of new technology and goal of giving the right intervention to the right patient at the right time, can be a great unifier between that digital technology and "the physical world," not least through harnessing research data and genomics to improve the lives of patients and enhance society [127]. SMEs must be involved at all levels of the process, and Europe as a whole must work harder to put them at the forefront as drivers of innovation.

\section{Regional Policies to Take Account of}

SME Differences and Unfair Competition from

\section{Multinational Companies}

There is a need to ensure a level playing field for SMEs regarding their competitive position compared with large corporations [128]. Small and local business is particularly disadvantaged in overregulated and bureaucratised administrative systems, as they induce higher fixed costs for enterprises [129]. In some cases, EU competition policy results in privileging big operators characterised by better economic efficiency than SMEs [130]. There is an increased need for specific SME measures in order to curb their market diseconomies, enabling SMEs' internationalisation and boosting their job creation potential. 
When shaping the EU's regulatory framework, policy impact analysis should make a difference between multinational companies and SMEs. At the same time, the strong regional differentiation among Member States should be given more consideration when assessing and measuring EU policy results. In light of divergent barriers to job creation, the principle of "one size fits all" is discriminatory for the SME sector.

There is a need for a stable regulatory environment, plus improved regulation quality and enforcement, to lower SMEs' burdens, including labour costs [131]. In this context, particular attention must be paid to specific measures needed to improve SMEs' access to skills. There is a need for further development of vocational education training that facilitates work-based learning and apprenticeships.

Above all, Member States should implement the “Think Small First" principle and provide favourable legislative frameworks for newly created SMEs [132].

\section{Spotlight on Rare Diseases and Role of SMEs}

In the EU, a disease is defined as rare if it is life-threatening or chronically debilitating and if no more than 1 in 2,000 people has it [133].

Ten years ago, the EU adopted a Communication setting out how it would support Member States in diagnosing, treating and caring for citizens with rare diseases [134]. The strategy's third pillar was to strengthen cooperation and coordination for rare disease research. Challenges are numerous due to the low prevalence, and research work is limited and scattered across laboratories and clinics. This scarcity of expertise and practice translates into delayed diagnosis, few medicinal products and difficult access to care [135].

Therefore, this is a prime example of having an EU strategy to encourage SMEs to develop and take on this challenge. The rewards for SMEs are substantial, with authorised orphan medicines benefiting from 10 years' protection from market competition once approved. This period of protection is extended by 2 years for medicines that have complied with an agreed paediatric investigation plan granted at the time of review of the orphan medicine designation [136]. This will require a new pricing and reimbursement model with coordinating assessments that will incentivise innovation across all disease areas where unmet medical needs exist, and not only in the areas where innovation and added value are most easily achieved and demonstrated [137].
Funding in the Rare Disease Area and Opportunities for SMEs

The EU has put much effort into funding rare disease research, encouraging national funding organisations to collaborate in the E-Rare programme [138].

Co-ordination of the activities between funding agencies, regulatory bodies, civil society organisations and partnerships with, for example, EU RIs maximises the impact of global investments for SMEs [139].

\section{Benefits for Society}

Between 2000 and September 2015, the EMA received 2,302 applications for designation, of which the Commission approved 1,544. Of these, 1,227 are currently active. Up to February 2016, the Commission authorised 119 products, of which $84 \%$ are new active substances [140]. Such activities contribute to accelerating the development of innovative therapeutic approaches. Without such incentives in the system there would be a lack of willingness by SMEs to enter this area.

\section{Conclusions and Policy Recommendations}

\section{Conclusions}

While cooperation between EU health systems is complex, the EU has all the necessary ingredients to shape a prosperous and safe future for SMEs [141]. An illustration of this is the research field, where there are 1.8 million researchers working at thousands of universities and research centres, as well as in world-leading manufacturing industries, a suite of increasingly interconnected research infrastructures, a thriving ecosystem and an increasing number of hotspots for start-ups [142]. Information exchange in the field offers the potential to both increase the efficiency of cross-border cooperation and reduce information gaps [76]. Such enhanced information exchange between research is vital to promote a knowledge transfer between regions and can support SMEs [143].

However, the issue of supporting SMEs in the health innovation sphere has no one-size-fits-all solution. Healthcare systems can act as closed systems in which service delivery, service use and financing take place within the national territory following the territory principle. Of course, lessons can be learnt from the research community and the structures that they have developed to tackle the thorny issues of stakeholders' motivations and interests to engage in cross-border cooperation [144]. A key rationale for cooperation is to provide benefits by 
translating the broad ideals and values of science and technology into concrete advantages for EU citizens [145].

Many new SMEs are active as a result of crowdfunding, and new entrepreneurial financing instruments have been introduced. These instruments are supporting SMEs that faced difficulties in the early stages of their development [144].

EU and Member State policies should support SMEs' scale-up by fostering a dynamic business environment that facilitates entrepreneurship and enables firms of all sizes to reach their full potential, including through better integration in regional, EU and global markets and value chains [146].

Tailored policies can ease access to, and effective use of, strategic resources by growth-oriented entrepreneurs and SMEs, including finance, skills, technology and knowledge. These policies must take place against the backdrop of sound framework conditions, including the institutional and regulatory framework enshrined in the single market, in order to ensure certainty and to incentivise experimentation by entrepreneurs.

\section{Policies for Inclusive SME Health Entrepreneurship}

On the basis of engagement with national and EU policy-makers, politicians and policy experts, a summary has been made of the recommendations.

\section{Policy Option to Facilitate SMEs as Drivers of} Health Innovation

1 Frameworks to Support SMEs

- Providing forms of support for the generational transfer of businesses: in Europe, there are many SMEs which are family businesses that have existed for more than 75 years. For these SMEs, there is a need to find ways to commercialise new and emerging technologies or apply existing technologies to new settings like healthcare; therefore, a transition framework needs to be put in place for scale-up and consolidation

- Reinforcing the EU Entrepreneurship 2020 Action Plan with budget lines after 2020 that can

(a) strengthen framework conditions for entrepreneurs by removing existing structural barriers,

(b) support entrepreneurs in crucial phases of the business life cycle and

(c) spread the culture of entrepreneurship in Europe in order to nurture a new generation of entrepreneurs in the healthcare area

- Medical technology SMEs are investing heavily to comply with new in vitro diagnostic regulations. How- ever, the industry's ability to keep products on the market, beyond the 26 May 2020 and 26 May 2022 deadlines, could be jeopardised by the slow progress in putting into place the critical infrastructure that will enable the new regulatory systems to work. As such, these deadlines should be extended by 2 years

- Providing specific forms of support for healthcare-focused SMEs in the framework of funding policies with the inclusion of genomics and data sharing in the criteria at the beginning so the inclusion of proposals such as MEGA is more logical at the end for funding

- Implementing an "SME test" so that every healthcarerelated legislative provision is accompanied by an impact assessment of the costs, ensuring a corresponding reduction of other charges, applying the principle of proportionality and specificity, and postponing compliance obligations:

(a) Ensuring that recommendations developed by the "EU Task force on subsidiarity, proportionality and doing less more efficiently" facilitate rather than hinder SME development

- Favouring the participation of SMEs in the health sector in the planning of initiatives and the reviewing of tools for internationalisation

2 Financing

- Implementing the Small Buisness Act (SBA) Action Plan recommendation that the cost of setting up a company be reduced to EUR 50 and the time required reduced to 2 days by 2020, and also implementing the SBA Action Plan recommendation by 2020 for rehabilitation and liquidation of the bankruptcy debts of honest business entrepreneurs to 1 year

- The EU supporting system of businesses and banks and other international forums should make sure that the roll-out of "Basel 3" capital adequacy rules does not hinder credit to SMEs and adversely affect the GDP [147]

- A greater percentage of Horizon Europe should be allocated to support SME innovation:

(a) Increased business innovation grants for feasibility assessment: EUR 250,000 (lump sum) per project (75\% of total cost of the project)

(b) Business innovation grants for innovation development and demonstration purposes (an amount in the indicative range between EUR 500,000 and EUR 2.5 million [75\% of total cost of the project] as a general rule)

(c) Define market access pathways to successfully support SMEs who obtain grants under (a) and (b) to ensure further development and marketability of new innovations
10

Public Health Genomics 2018;21:1-17 DOI: $10.1159 / 000492809$
Horgan/van Kranen/Morré 
Table 1. Interactive summary of the SME recommendations

\begin{tabular}{lll}
\hline Policy recommendation & Subsection & Proposed action \\
\hline $\begin{array}{l}\text { Frameworks to } \\
\text { support SMEs }\end{array}$ & Generational transfer of businesses & $\begin{array}{l}\text { Funding and support frameworks } \\
\text { created or adapted from other domains } \\
\text { that are tailored to healthcare for scale- } \\
\text { up and consolidation }\end{array}$ \\
\cline { 2 - 3 } & $\begin{array}{ll}\text { Reinforce EU Entrepreneurship 2020 } \\
\text { Action Plan }\end{array}$ & $\begin{array}{l}\text { Sustainable funding; support network at } \\
\text { EU, Member State and national levels }\end{array}$
\end{tabular}

Action Plan

EU, Member State and national levels

Outcome

Sustainability within the local systems and ownership among local actors which understand the organisational culture, thereby facilitating tailored responses

Provides structured guidance for entry into new markets and points of contact to receive advice on challenges faced (e.g. technical, financial, political, etc.)

Realistic timeline for regulatory and legislative transposition in the Member States

Targeted funding for SMEs in healthcare-related areas to support a healthcare system adapting innovative cost-saving healthcare solutions
Early dialogue with SMEs so as to take account of the financial burden and modify transition phases for groups of enterprises if needed

Equal percentage of funding given to the health domains compared to other traditional areas (e.g. environment, transport, energy, etc.) in industrial strategy provided to healthcare SMEs and inclusion of specific criteria that will ensure support drives innovative healthcare technologies

"SME test" so that every healthcare- Impact assessment carried out to

Financing Implementing the SBA Action Plan
related legislative provision is accompanied by an impact assessment of the costs

Involvement of the planning of initiatives and the reviewing of tools for internationalisation recommendation comprehend the impact on future SME business strategies to enable innovation

Joint EU and/or Member State stakeholder meetings with SMEs and online consultation opened

Timeline reduced to 2 days and for cost incorporation reduced to EUR 50 by 2020 and rehabilitation to 1 year for liquidation

Making sure the "Basel 3" capital adequacy rules do not hinder credit to SMEs

Specific mention included of SMEs in the healthcare arena and in any extension to "Basel 3" or subsequent agreement

Increased access to funding within Horizon Europe and alignment with Member States' envelopes of funding

Ensure sustained funding to act as an incubator for SMEs in the healthcare sector and funding for SMEs to scale up
Ensure that SMEs can survive regulatory changes and there are feedback loops so that the regulator can take account of difficulties

Attract new SMEs in the healthcare area that could have applied similar expertise to another domain; increased SME skill sets developed that can support an innovative health ecosystem

Responsive regulatory framework that enables, and does not hinder, the creation, entry and scale-up of SMEs

Increased growth of EU SMEs that reach the SME category of a unicorn

Increased willingness of SMEs to undertake risks so as to generate innovation

Increased access to funding for SMEs to undertake and sustain their business

Increased number of SMEs that will have seed funding and funding that will allow the healthcare systems to be adaptive to innovation

Data Coordination between healthcare authorities and ministries of regions and Member States to implement the secure exchange of data sets and technical interoperability

EU activities such as MEGA provide a mechanism to coordinate and harmonise standards of interoperability within a context; such common objectives should be increased and resources allocated to ensure that they reach their agreed objective

Ensuring European standards, guidelines and interoperability are implemented and reviewed by the EU and Member States on a 3-year basis
Increased alignment regarding interoperability standards that can be updated to take account of the evolution in healthcare
Mission-type projects such as MEGA act as a fulcrum and a one-stop objective which SMEs and the public sector can work towards

Increased collaboration between public and private sector as the regulatory framework supports a data-driven healthcare system that is responsive to innovation 
Table 1 (continued)

\begin{tabular}{|c|c|c|c|}
\hline Policy recommendation & Subsection & Proposed action & Outcome \\
\hline \multirow[t]{2}{*}{ Market access } & $\begin{array}{l}\text { European single market for healthcare } \\
\text { products and services }\end{array}$ & $\begin{array}{l}\text { The "four freedoms" of free movement } \\
\text { of goods, capital, services and labour are } \\
\text { applicable to the healthcare sector, } \\
\text { which facilitates their adoption in } \\
\text { healthcare sectors, and resistance/ } \\
\text { discrimination due to disruptive } \\
\text { innovation is mitigated by EU single } \\
\text { market internal rules }\end{array}$ & $\begin{array}{l}\text { Earlier adoption of health innovation, } \\
\text { which leads to cost efficiency, sharing of } \\
\text { best practices and better outcomes for } \\
\text { patients and avoids harmful effects of } \\
\text { diseases on citizens at a later stage }\end{array}$ \\
\hline & Reinforce regulatory frameworks & $\begin{array}{l}\text { A regulatory framework that can } \\
\text { support the development of treatment/ } \\
\text { diagnostics for smaller patient } \\
\text { populations should be a priority, as this } \\
\text { is the future of healthcare based on an } \\
\text { understanding of science stratifying } \\
\text { patient populations }\end{array}$ & $\begin{array}{l}\text { Greater willingness of SMEs to enter the } \\
\text { rare disease/stratified medicine area so } \\
\text { as to develop solutions; without such } \\
\text { incentives, SMEs could not enter, as } \\
\text { there would not be a return on their } \\
\text { investment; the EU can become a } \\
\text { market leader with such regulatory } \\
\text { frameworks }\end{array}$ \\
\hline
\end{tabular}

\section{Data}

- Supporting coordination between authorities to implement the secure exchange of genomic and other health data in order to advance research and personalised medicine

- Ensuring European standards, guidelines and interoperability are in place for the healthcare ecosystem which are implemented and assessment is undertaken on a 3-year basis for review and update, taking into account the evolution of innovation. Standards should help reduce technical barriers to healthcare transactions, reduce costs and facilitate SMEs' access to markets [148]

\section{Market Access}

- With more than 430 million consumers (minus the UK after Brexit), the European single market for healthcare products and services provides many opportunities for intra-EU trade for SMEs. The Commission's objective should ensure a stable regulatory framework to foster free movement of healthcare products and to ensure frameworks can facilitate their adoption in the healthcare setting

- Reinforcing regulatory frameworks such as the Orphan Regulation for Rare Disease that can support SMEs and can ensure equality of access for all [149]

\section{Access to Information}

- Providing access to health innovation market information through the following EU portals:

- Fit for Health 2.0: for SMEs in the life sciences sector, which provides:

- a database containing quality-checked researchers and SMEs acting in the life sciences sector and

- advice on all aspects related to EU-funded research projects, such as first orientation, strategy development, proposal preparation, implementation, exploitation and promotion

- Enterprise Europe Network: a tailored section that facilitates SMEs active in health innovation to get access to market information, overcome legal obstacles and find potential business partners across Europe

- Internationalisation of Clusters in the health sphere: this initiative should promote international cluster cooperation and collaboration by intensifying cluster and business network opportunities across borders and sectoral boundaries within and beyond Europe

Interactive Summary of the SME Recommendations (Table 1)
Horgan/van Kranen/Morré 


\section{Disclosure Statement}

S.A.M. is $100 \%$ employed by the VU University Medical Center Amsterdam, and the Maastricht University Medical Center is involved in SMEs as a co-founder and CSO (Microbiome) and CEO
(TubaScan) in spin-off companies of the VU University Medical Center Amsterdam, The Netherlands. H.J.v.K. has a 4-h-per-week appointment at TubaScan to accommodate his IPHG position. D.H. has no conflicts of interest to declare.

\section{References}

1 "Think Small First": A Small Business Act for Europe - Europa EU. www.consilium.europa.eu/uedocs/cms_Data/docs/pressdata/en/ intm/104403.pdf (cited July 30, 2018).

2 Communication from the Commission to the European Parliament, the Council, the European Economic and Social Committee and the Committee of the Regions "Small Business, Big World - a new partnership to help SMEs seize global opportunities." https://eur-lex.europa.eu/legal-content/EN/ALL/?uri=CELEX: 52011DC0702 (cited July 30, 2018).

3 Maastricht Treaty - Europa EU. https://europa.eu/european-union/sites/europaeu/ files/docs/body/treaty_on_european_union_ en.pdf (cited July 30, 2018).

4 Negrouk A, Lacombe D, Meunier F: Diverging EU health regulations: the urgent need for co ordination and convergence. J Cancer Policy 2017 , in press.

5 Annual Report on European SMEs 2016/2017. Focus on self-employment. https://publications.europa.eu/en/publication-detail/-/ publication/0b7b64b6-ca80-11e7-8e6901aa75ed71a1/language-en (cited August 2, 2018).

6 Reijonen H, Tammi T, Saastamoinen J: SMEs and public sector procurement: does entrepreneurial orientation make a difference? Int Small Business J 2016;34:468-486.

7 McCann P, Ortega-Argilés R: Smart specialisation, entrepreneurship and SMEs: issues and challenges for a results-oriented EU regional policy. Small Business Econ 2016;46: 537-552.

8 Communication from the Commission to the European Parliament, the Council, the European Economic and Social Committee and the Committee of the Regions on enabling the digital transformation of health and care in the Digital Single Market; empowering citizens and building a healthier society. https:// eur-lex.europa.eu/legal-content/EN/ ALL/?uri=COM\%3A2018\%3A233\%3AFIN (cited August 2, 2018).

9 Fact Sheets on the European Union: small and medium-sized enterprises. http://www.europarl.europa.eu/factsheets/en/sheet/63/ small-and-medium-sized-enterprises (cited August 2, 2018).

10 Treaty on the Functioning of the European Union. https://eur-lex.europa.eu/legal-content/EN/TXT/?uri=OJ:C:2016:202:TOC (accessed July 27, 2018).
11 European Commission: Recommendation 2003/361/EC. 2003. https://www.ip-watch. org/2016/07/05/the-dutch-pharma-policy-agroundbreaking-presidency/ (cited July 27, 2018).

12 European Commission: What is an SME? http://ec.europa.eu/growth/smes/businessfriendly-environment/sme-definition_en (accessed August 8, 2018).

13 https://ec.europa.eu/growth/access-to-finance_en (accessed August 2, 2018).

14 Eurobarometer Poll: two years until the 2019 European Elections. http://www.europarl.europa.eu/at-your-service/en/be-heard/eurobarometer/two-years-until-the-2019-european-elections (cited July 27, 2018).

15 Spring 2018 Standard Eurobarometer. http:// ec.europa.eu/commfrontoffice/publicopinion/index.cfm/Survey/getSurveyDetail/instruments/STANDARD/surveyKy/2180 (cited July 27, 2018).

16 Flynn A, Davis P: Firms' experience of SMEfriendly policy and their participation and success in public procurement. J Small Business Enterprise Dev 2016;23:616-635.

17 Jeremy Hunt admits parts of the NHS are providing "unacceptable" care. https://www.independent.co.uk/news/uk/politics/jeremyhunt-nhs-crisis-winter-unacceptable-carebbc-interview-a7572686.html (cited July 27, 2018).

18 Harper S: Economic and social implications of aging societies. Science 2014;346:587-591.

19 Suzman R, Beard JR, Boerma T, Chatterji S: Health in an ageing world - what do we know? Lancet 2015;385:484-486.

20 Communication from the Commission to the European Parliament, the Council, the European Economic and Social Committee and the Committee of the regions: a budget for Europe 2020. https://eur-lex.europa.eu/legal-content/ EN/ALL/?uri=CELEX:52011DC0500 (cited July 27,2018 ).

21 Mol-Gómez-Vázquez A, Hernández-Cánovas G, Koëter-Kant J: Legal and institutional determinants of factoring in SMEs: empirical analysis across 25 European countries. J Small Business Manag 2018;56:312-329.

22 Marangos S, Warren L: A mapping for managers: open innovation for $R \& D$ intensive SMEs in the life sciences sector. Eur J Innovation Manag 2017;20:210-229.

23 Ipinnaiye O, Dineen D, Lenihan H: Drivers of SME performance: a holistic and multivariate approach. Small Business Econ 2017;48:883911.
24 LAB-FAB-APP: Investing in the European future we want. http://ec.europa.eu/research/ evaluations/pdf/archive/other_reports_studies_and_documents/hlg_2017_report.pdf (cited July 28, 2018).

25 Management Plan 2018, DG Connect - European Commission. https://ec.europa.eu/info/ sites/info/files/management-plan-grow-2018_ en.pdf (cited July 28, 2018).

26 European Commission: Press Release: EU budget: Commission proposes $€ 9.2$ billion investment in first ever digital programme. europa.eu/rapid/press-release_IP-18-4043_ en.pdf (cited July 28, 2018).

27 European Commission: Press Release: Juncker Plan supports $€ 40$ million loan to finance research of cancer treatment. http://europa. eu/rapid/press-release_MEX-18-4721_ en.htm (cited July 28, 2018).

28 Cao S: EU proposes $\$ 11 \mathrm{~B}$ tech innovation fund to catch up with Silicon Valley. http:// observer.com/2018/06/eu-proposes-tech-innovation-fund (cited July 28, 2018).

29 Autio E: Entrepreneurship Support in Europe: Trends and Challenges for EU Policy. London, Imperial College Business School, 2016.

30 Annual Report on European SMEs 2016/2017. https://ec.europa.eu/docsroom/documents/26563/attachments/1/translations/ en/.../pdf (cited July 28,2018 ).

31 Health at a Glance: Europe 2016 - State of Health in the EU Cycle. https://ec.europa.eu/ docsroom/documents/26563/attachments/1/ translations/en/.../pdf (cited July 28, 2018).

32 Communication from the Commission to the European Parliament, the European Council, the Council, the European Economic and Social Committee and the Committee of the Regions: a renewed European Agenda for Research and Innovation - Europe's chance to shape its future: the European Commission's contribution to the Informal EU Leaders' meeting on innovation in Sofia on 16 May 2018. https://ec.europa.eu/info/sites/info/ files/com-2018-306-a-renewed-europeanagenda-_for_research-and-innovation may_2018_en_0.pdf (cited July 28, 2018).

33 Annual Report on European SMEs 2016/2017. https://ec.europa.eu/docsroom/documents/26563/attachments/1/translations/ en/.../pdf (cited July 28,2018 ).
Optimising SME Potential in Modern

Healthcare Systems
Public Health Genomics 2018;21:1-17 DOI: $10.1159 / 000492809$ 
34 Are EU SMEs recovering from the crisis? Annual Report on EU Small and Medium Sized Enterprises 2010/2011. https://ec.europa.eu/ docsroom/documents/15770/attachments/1/ translations/en (cited August 2, 2018).

35 Draft Joint Employment Report from the Commission and the Council accompanying the Communication from the Commission on the Annual Growth Survey 2018. https:// eur-lex.europa.eu/legal-content/EN/ TXT/?uri=CELEX\%3A52017DC0674 (cited August 2, 2018).

36 European Commission: Growing the European Silver Economy. http://ec.europa.eu/research/innovation-union/pdf/activehealthy-ageing/silvereco.pdf (cited July 28, 2018).

$37 \mathrm{New}$ initiatives to assist small enterprises to go international. https://ec.europa.eu/ growth/content/new-initiatives-assist-smallenterprises-go-international-0_en (cited July 28, 2018).

38 Europe's IPO market heats up, and unicorns are getting in line. https://www.cnbc.com/ 2018/06/19/europes-ipo-market-heats-upand-unicorns-are-getting-in-line.html (cited July 28, 2018).

39 Cusmano L, Koreen M, Pissareva L: 2018 OECD Ministerial Conference on SMEs. 2018.

40 European Commission: Issue papers for the High Level Group on maximizing the impact of $\mathrm{EU}$ research and innovation programmes. https://ec.europa.eu/research/evaluations/ pdf/hlg_issue_papers.pdf (cited July 28, 2018).

41 Europe's next leaders: the Start-Up and ScaleUp Initiative - Communication from the Commission to the European Parliament, the Council, the European Economic and Social Committee and the Committee of the Regions. https://eur-lex.europa.eu/legal-content/EN/TXT/?uri=COM:2016:733:FIN (cited July 28,2018 ).

42 Joint Report by the Commission services and the Economic Policy Committee on Health Care and Long-Term Care Systems and Fiscal Sustainability, European Commission and Economic Policy Committee, October 2016. https://ec.europa.eu/info/publications/economy-finance/joint-report-health-care-andlong-term-care-systems-fiscal-sustainability-0_en (cited July 30, 2018).

43 Janger J, Schubert T, Andries P, Rammer C, Hoskens M: The EU 2020 innovation indicator: a step forward in measuring innovation outputs and outcomes? Res Pol 2017;46:3042.

44 OECD/EU: The Missing Entrepreneurs 2017: Policies for Inclusive Entrepreneurship. Paris, OECD Publishing, 2017. https://doi.org/ 10.1787/9789264283602-en.

45 Europe's IPO market heats up, and unicorns are getting in line. https://ca.finance.yahoo. com/news/europe-apos-ipo-marketheats-142300035.html?guccounter=1 (cited July 30,2018$)$.
46 LAB-FAB-APP: Investing in the European future we want: report of the independent High Level Group on maximising the impact of EU Research and Innovation Programmes. http://ec.europa.eu/research/evaluations/ pdf/archive/other_reports_studies_and_ documents/hlg_2017_report.pdf (cited July 28, 2018).

47 Nimmesgern E, Benediktsson I, Norstedt I: Personalized medicine in Europe. Clin Transl Sci 2017;10:61-63.

48 Closing speech by Commissioner Moedas at the conference "Research and Innovation Shaping Our Future." http://europa.eu/rapid/ press-release_SPEECH-17-1881_en.htm (cited July 28, 2018).

49 European Commission: Global Europe 2050. https://ec.europa.eu/research/social-sciences/pdf/policy_reviews/global-europe2050-report_en.pdf (cited August 3, 2018).

50 European Commission: Annual Report on European SMEs 2016/2017. https://ec.europa.eu/docsroom/documents/26563/attachments/1/translations/en/renditions/native (cited July 28, 2018)

51 Communication from the Commission to the European Parliament, the Council, the European Economic and Social Committee and the Committee of the Regions: Europe's next leaders: the Start-Up and Scale-Up Initiative. https://eur-lex.europa.eu/legal-content/EN/ $\mathrm{TXT} /$ ?uri=COM\%3A2016\%3A733\%3AFIN (cited August 3, 2018).

52 Blanchflower DG, Levine PB, Zimmerman DJ: Discrimination in the small-business credit market. Rev Econ Stat 2003;85:930943.

53 Commission recommendation on a new approach to business failure and insolvency. https://eur-lex.europa.eu/legal-content/EN/ TXT/?uri=celex\%3A32014H0135 (cited July 28, 2018).

54 Final report: study on the representativeness of business organisations for SMEs in the European Union. https://ec.europa.eu/DocsRoom/documents/2480/attachments/1/ translations/en/renditions/pdf (cited August 3, 2018).

55 European Economic Forecast: Winter 2017. https://infoeuropa.eurocid.pt/files/database/000069001-000070000/000069966.pdf (cited August 3, 2018).

56 European Parliament Briefing May 2016: barriers to SME growth in Europe. http://www. europarl.europa.eu/RegData/etudes/ BRIE/2016/583788/EPRS_BRI(2016)583788_ EN.pdf (cited July 28, 2018).

57 European Commission: Global Europe, 2050. https://ec.europa.eu/research/social-sciences/pdf/policy_reviews/global-europe2050-report_en.pdf (cited July 28, 2018).

58 The "Survey on the access to finance of enterprises" (SAFE) was published today. https:// ec.europa.eu/growth/content/survey-accessfinance-enterprises-safe-was-published-today_en (cited July 30, 2018).
59 European Parliament Report on how best to harness the job creation potential of small and medium-sized enterprises (SMEs). http:// www.europarl.europa.eu/sides/getDoc. do? pubRef $=-/ /$ EP//TEXT+REPORT +A 82016-0248+0+DOC+XML+V0//EN (cited August 3, 2018).

60 Report on the public consultation on the "New SME Policy." http://ec.europa.eu/DocsRoom/documents/8986/attachments/1/ translations (cited July 28, 2018).

61 Joint Communication to the European Parliament, the Council, the European Economic and Social Committee and the Committee of the Regions: a new response to a changing neighbourhood. https://eur-lex.europa.eu/ legal-content/en/ALL/? uri=CELEX: 52011DC0303 (cited July 28, 2018).

62 Why are so many of our health services provided by charities? https://www.irishtimes. com/life-and-style/health-family/why-areso-many-of-our-health-services-providedby-charities-1.3300058 (cited July 28, 2018).

63 OECD Key Issue Paper: SME Ministerial Conference: Strengthening SMEs and entrepreneurship for productivity and inclusive growth. https://www.oecd.org/cfe/smes/ministerial/documents/2018-SME-MinisterialConference-Key-Issues.pdf (cited July 28, 2018).

64 Kirshbaum MN, Dent J, Stephenson J, Topping AE, Allinson V, McCoy M, Brayford S: Open access follow-up care for early breast cancer: a randomised controlled quality of life analysis. Eur J Cancer Care (Engl) 2017; 26:e12577.

65 France, Germany, Italy, Spain and the United Kingdom: Internationalisation of European SMEs - Taking Stock and Moving Ahead. https://www.british-business-bank.co.uk/ wp-content/uploads/2018/03/Internationalisation-of-European-SMEs-2018-FINALVERSION.pdf (cited July 28, 2018).

66 Communication from the Commission to the European Parliament, the Council, the European Economic and Social Committee and the Committee of the Regions on the MidTerm Review of the Capital Markets Union Action Plan. https://ec.europa.eu/info/sites/ info/files/communication-cmu-mid-termreview-june2017_en.pdf (cited August 3, 2018).

67 European Parliament Report on access to finance for SMEs and increasing the diversity of SME funding in a Capital Markets Union (2016/2032[INI]). http://www.europarl.europa.eu/sides/getDoc.do?pubRef=-//EP// TEXT+REPORT+A8-2016-0222+0+DOC+ $\mathrm{XML}+\mathrm{V0//EN} \mathrm{(cited} \mathrm{August} \mathrm{8,} \mathrm{2018).}$

68 European Parliament Briefing: SME support in EU regions. http://www.europarl.europa. eu/RegData/etudes/BRIE/2015/568354/ EPRS_BRI(2015)568354_EN.pdf (cited August 8,2018 )

69 Private cancer therapy "crowdfunding rise." https://www.bbc.com/news/health-38858898 (cited July 28, 2018). 
70 Agrawal A, Catalini C, Goldfarb A: Crowdfunding: geography, social networks, and the timing of investment decisions. J Econ Manag Strat 2015;24:253-274.

71 Rabeharisoa V: The struggle against neuromuscular diseases in France and the emergence of the "partnership model" of patient organisation. Soc Sci Med 2003;57:21272136.

72 Oliver T: Building an entrepreneurial patient movement: a global case study from the AKU Society; in Sireau N (ed): Rare Diseases: Challenges and Opportunities for Social Entrepreneurs. Sheffield, Greenleaf, 2013, pp 43-61.

73 Financing programmes for SMEs. https:// ec.europa.eu/info/business-economy-euro/ growth-and-investment/financing-investment/financing-programmes-smes_en (cited July 28, 2018).

74 The Lancet Oncology: Mind the gap: charity and crowdfunding in health care. Lancet Oncol 2017;18:269.

75 Renwick MJ, Mossialos E: Crowdfunding our health: economic risks and benefits. Soc Sci Med 2017;191:48-56.

76 Khoumbati K, Themistocleous M, Irani Z: Evaluating the adoption of enterprise application integration in health-care organizations. J Manag Inf Syst 2006;22:69-108.

77 Marangos S, Warren L: A mapping for managers: open innovation for R\&D intensive SMEs in the life sciences sector. Eur J Innov Manag 2017;20:210-229.

78 Swinkels ICS, Huygens MWJ, Schoenmakers TM, Oude Nijeweme-D'Hollosy W, van Velsen L, Vermeulen J, et al: Lessons learned from a living lab on the broad adoption of eHealth in primary health care. J Med Internet Res 2018;20:e83.

79 Goldman M, Compton C, Mittleman BB: Public-private partnerships as driving forces in the quest for innovative medicines. Clin Transl Med 2013;2:2.

80 Nassr IK, Wehinger G: Opportunities and limitations of public equity markets for SMEs. OECD J Financ Market Trends 2016;2015: $49-84$.

81 Gassmann O, Schuhmacher A, von Zedtwitz $M$, Reepmeyer G: The open innovation challenge: how to partner for innovation; in Leading Pharmaceutical Innovation. Cham, Springer, 2018, pp 111-133.

82 Zuckerman DM, Jury NJ, Silcox CE: 21st Century Cures Act: fast-track to cure or morbidity? Pharm Med 2016;30:117-118.

83 Van Norman GA: Drugs and devices: comparison of European and US approval processes. JACC Basic Transl Sci 2016;1:399412.

84 Proposal for a Regulation of the European Parliament and of the Council amending Regulations (EU) No 596/2014 and (EU) $2017 / 1129$ as regards the promotion of the use of SME growth markets. https://eur-lex. europa.eu/legal-content/EN/TXT/?uri= COM\%3A2018\%3A331\%3AFIN (cited July $28,2018)$.
85 Public consultation on strengthening EU cooperation on Health Technology Assessment (HTA). https://ec.europa.eu/health/technology_assessment/consultations/cooperation_ hta_en (cited August 3, 2018).

86 SME Investment and Innovation - France, Germany, Italy and Spain. https://www.kfw. de/PDF/Download-Center/Konzernthemen/ Research/PDF-Dokumente-Studien-undMaterialien/SME-Investment-and-Innovation-October-2015.pdf (cited August 3, 2018).

87 Horgan D, Romao M, Hastings R: Pulling the strands together: MEGA steps to drive European genomics and personalised medicine. Biomed Hub 2017;2(suppl 1):481300.

88 European Commission - Fact Sheet: the digital transformation of healthcare. http://europa.eu/rapid/press-release_MEMO-18-3367 en.htm (cited July 28, 2018).

89 Declaration of Cooperation: towards access to at least 1 million sequenced genomes in the European Union by 2022. https://ec.europa. eu/digital-single-market/en/news/eu-countries-will-cooperate-linking-genomic-databases-across-borders (cited July 28, 2018).

90 Declaration of Cooperation: towards access to at least 1 million sequenced genomes in the European Union by 2022. https://ec.europa. eu/digital-single-market/en/news/eu-countries-will-cooperate-linking-genomic-databases-across-borders (cited July 28, 2018)

91 European Commission: Communication on enabling the digital transformation of health and care in the Digital Single Market; empowering citizens and building a healthier society. https://ec.europa.eu/digital-single-market/ en/news/communication-enabling-digitaltransformation-health-and-care-digital-single-market-empowering (cited July 28, 2018).

92 Commission Staff Working Document: A Digital Single Market Strategy for Europe Analysis and Evidence. https://eur-lex.europa.eu/legal-content/EN/ALL/? uri=celex: 52015SC0100 (cited July 28, 2018).

93 EAPM White Paper on Lung Cancer in Europe. https://www.euapm.eu/pdf/EAPM White_Paper_on_Lung_Cancer_-_PM.pdf (cited August 3, 2018).

94 EAPM White Paper on Melanoma in Europe. https://euapm.eu/pdf/EAPM_THE_MELANOMA_WHITE_PAPER.pdf (cited August 3, 2018).

95 EAPM White Paper on Pancreatic Cancer in Europe. https://euapm.eu/pdf/EAPM_Eapancreatic_cancer_white_paper_2015.pdf (cited August 3, 2018).

96 Regulation (EU) No 536/2014 of the European Parliament and of the Council of 16 April 2014 on clinical trials on medicinal products for human use, and repealing Directive 2001/20/EC; OJ L 158/1-76, 27.5.2014. https://eur-lex.europa.eu/legal-content/EN/ TXT/?uri=CELEX:32014R0536 (cited July 30, 2018).
97 Regulation (EU) 2016/679 of the European Parliament and of the Council of 27 April 2016 on the protection of natural persons with regard to the processing of personal data and on the free movement of such data, and repealing Directive 95/46/EC (General Data Protection Regulation); OJ L 119/1-88, 4.5.2016. https://eur-lex.europa.eu/legal-content/EN/TXT/?uri=CELEX\%3A32016R0679 (cited July 30, 2018).

98 Council of the European Union: Modernising EU rules for medical devices. http:// www.consilium.europa.eu/en/policies/newrules-medical-in-vitro-diagnostic-devices/ (cited July 30, 2018).

99 Directive 2011/24/EU of the European Parliament and of the Council of 9 March 2011 on the application of patients' rights in cross-border healthcare, OJ L 88 of 4.4.2011. https://eur-lex.europa.eu/legal-content/ EN/ALL/?uri=celex\%3A32011L0024 (cited July 30,2018 ).

100 https://ec.europa.eu/eip/ageing/home_en (cited July 30, 2018).

101 http://www.aal-europe.eu/ (cited July 30, 2018).

102 Council Regulation (EU) No 557/2014 of 6 May 2014 establishing the Innovative Medicines Initiative 2: Joint Undertaking, OJ L 169 of 7.6.2014. https://eur-lex.europa.eu/ legal-content/EN/TX T/ ? u ri= uriserv:OJ.L_.2014.169.01.0054.01.ENG (cited July 30, 2018).

103 Call for SMEs to tackle health challenges together with healthcare professionals. https:// ec.europa.eu/digital-single-market/en/ news/call-smes-tackle-health-challengestogether-healthcare-professionals (cited July 30, 2018).

104 Communication from the Commission to the European Parliament, the Council, the European Economic and Social Committee and the Committee of the Regions: eHealth Action Plan 2012-2020 - innovative healthcare for the 21st century. https://ec.europa. $\mathrm{eu} /$ health/sites/health/files/ehealth/docs/ com_2012_736_en.pdf (cited July 30, 2018).

105 Council of the European Union: Personalised medicine for patients - Council conclusions (7 December 2015). http://data. consilium.europa.eu/doc/document/ST15054-2015-INIT/en/pdf (cited July 30, 2018).

106 European Council meeting (28 June 2018) Conclusions. http://www.europeanmigrationlaw.eu/documents/EUCO-Conclusions-June\%202018_0.pdf (cited July 28, 2018).

107 Strategy Report on Research Infrastructures Roadmap 2010. https://ec.europa.eu/research/infrastructures/pdf/esfri-strategy report_and_roadmap.pdf (cited July 28, 2018).

108 European Strategy Forum on Research Infrastructures: Roadmap 2018. http://www. esfri.eu/roadmap-2018 (accessed July 30, 2018).
Optimising SME Potential in Modern

Healthcare Systems
Public Health Genomics 2018;21:1-17 DOI: $10.1159 / 000492809$ 
109 European Commission: European Commission awards EU legal status to four research infrastructures. http://europa.eu/rapid/ press-release_MEMO-13-1073_en.htm (accessed July 30, 2018).

110 European Commission: Proposal for a Council Regulation amending Regulation (EC) No 723/2009 concerning the Community legal framework for a European Research Infrastructures Consortium (ERIC). 2012. http:// eur-lex.europa.eu/LexUriServ/LexUriServ. do?uri=COM: 2012:0682:FIN:EN:PDF (accessed July 30, 2018).

111 The Academy of Medical Sciences. https:// acmedsci.ac.uk (accessed July 30, 2018).

112 Leopoldina Nationale Akademie der Wissenschaften. https://www.leopoldina.org/ leopoldina-home/ (accessed July 30, 2018).

113 Leopoldina Nationale Akademie der Wissenschaften, acatech Deutsche Akademie der Technikwissenschaften, Union der Deutschen Akademien der Wissenschaften: Individualised Medicine: Prerequisites and Consequences. www.leopoldina.org/uploads/tx_leopublication/2014_Stellungnahme_IndividualisierteMedizin_EN.pdf (accessed July 30, 2018).

114 Bundesministerium für Bildung und Forschung. www.gesundheitsforschung-bmbf. de/de/4950.php (accessed July 30, 2018).

115 Aviesan: Plan France Médecine Génomique 2025. http://aviesan.fr/en/aviesan/accueil/ toute-l-actualite/plan-france-medecine-genomique-2025 (accessed July 30, 2018).

116 European Parliamentary Research Service: Helping European SMEs to grow - start-up and scale-up initiatives for business ventures in the EU. http://www.europarl.europa.eu/ RegData/etudes/IDAN/2017/603967/ EPRS_IDA(2017)603967_EN.pdf (cited July 28, 2018)

117 European Commission: Trade, Growth and World Affairs: Trade Policy as a Core Component of the EU's 2020 Strategy. http:// trade.ec.europa.eu/doclib/docs/2010/november/tradoc_146955.pdf (cited July 28, 2018).

118 European Commission Communication: Review of the "Small Business Act" for Europe. https://eur-lex.europa.eu/legal-content/FRF/ TXT/?uri=celex:52011DC0078 (cited July 28, 2018).

119 European Commission Communication: Time to establish a modern, fair and efficient taxation standard for the digital economy. https://eur-lex.europa.eu/legal-content/ EN/TXT/?uri=COM:2018:0146:FIN (cited July 28, 2018).

120 OECD: Management Training in SMEs. https://www.oecd.org/cfe/smes/2492440. pdf (cited August 3, 2018).
121 Communication from the Commission to the European Parliament, the European Council, the Council, the European Economic and Social Committee and the Committee of the Regions: a renewed European Agenda for Research and Innovation - Europe's chance to shape its future: the European Commission's contribution to the Informal EU Leaders' meeting on innovation in Sofia on 16 May 2018. https://eur-lex.europa.eu/legal-content/EN/ $\mathrm{TXT} /$ ?uri=COM\%3A2018\%3A306\%3AFIN (cited August 3, 2018).

122 Report from the Working Group meeting on Bringing Digital Innovation Hubs together and sharing best practices held on 22 January 2018 in Brussels, Belgium. https://ec.europa.eu/futurium/en/system/files/ged/digital_innovation_hubs_working_group_ meeting_report_22_january_2018.pdf (cited July 28, 2018).

123 European Commission: Horizon 2020: e-infrastructures. https://ec.europa.eu/prog r a m mes/horizon $2020 /$ e n / h2020-section/e-infrastructures (cited July $28,2018)$.

124 First report of High Level Expert Group on the European Open Science Cloud. https:// ec.europa.eu/digital-single-market/en/ news/first-report-high-level-expert-groupeuropean-open-science-cloud (cited July 28 , 2018).

125 European Commission: Funding - Awareness - Scale - Talent (FAST); Europe is back: Accelerating Breakthrough Innovation: Full set of recommendations from the Independent High-Level Group of Innovators on establishing a European Innovation Council. https://ec.europa.eu/info/sites/info/files/ eic_hlg_bz_web.pdf (cited July 28, 2018).

126 European Commission: Special Eurobarometer 460: Report: Attitudes towards the impact of digitisation and automation on daily life. 2017. http://ec.europa.eu/commfrontoffice/publicopinion/index.cfm/ResultDoc/ download/DocumentKy/78997 (cited July 28, 2018).

127 Digitising European Industry. https:// ec.europa.eu/digital-single-market/en/policies/digitising-european-industry (cited July 28, 2018).

128 Open Science Policy Platform. https:// ec.europa.eu/research/openscience/index. $\mathrm{cfm}$ ?pg=open-science-policy-platform (cited July 28, 2018)

129 EAPM EU Irish Presidency Report: Innovation and Patient Access to Personalized Medicine. https://www.euapm.eu/pdf/ EAPM_REPORT_on_Innovation_and_Patient_Access_to_Personalised_Medicine. pdf (cited August 3, 2018).

130 OECD Policy Brief: Small and MediumSized Enterprises: Local Strength, Global Reach. http://www.oecd.org/cfe/leed/ 1918307.pdf (cited August 3, 2018).
131 Council conclusions (adopted on 27/05/2016). RECH 208 TELECOM 100. http://data.consilium.europa.eu/doc/document/ST-9526-2016-INIT/en/pdf (cited July 28, 2018).

132 Regulatory Policy: Towards a New Agenda: Pathways to the Future. https://www.oecd. org/gov/regulatory-policy/47298590.pdf (cited July 28, 2018).

133 LAB-FAB-APP: Investing in the European future we want: report of the independent High Level Group on maximising the impact of EU Research and Innovation Programmes. http://ec.europa.eu/research/ evaluations/pdf/archive/other_reports studies_and_documents/hlg_2017_report. pdf (cited July 28, 2018).

134 European Commission: The Small Business Act for Europe. https://ec.europa.eu/ growth/smes/business-friendly-environment/small-business-act_en (cited August 2, 2018).

135 Council Recommendation of 8 June 2009 on an action in the field of rare diseases. https:// eur-lex.europa.eu/legal-content/EN/ALL/? uri=celex\%3A32009H0703\%2802\%29 (cited August 2, 2018).

136 Communication from the Commission to the European Parliament, the Council, the European Economic and Social Committee and the Committee of the Region on Rare Diseases: Europe's challenges. https:// ec.europa.eu/health/ph_threats/non_com/ docs/rare_com_en.pdf (cited August 3, 2018).

137 European Commission: Innovative Payment Models for High-Cost Innovative Medicines. Report of the Expert Panel on Effective Ways of Investing in Health (EXPH). https://ec.europa.eu/health/expert_panel/ sites/expertpanel/files/docsdir/opinion_innovative_medicines_en.pdf (cited August 3, 2018).

138 Dharssi S, Wong-Rieger D, Harold M, Terry $S$ : Review of 11 national policies for rare diseases in the context of key patient needs. Orphanet J Rare Dis 2017;12:63.

139 Franco P: Orphan drugs: the regulatory environment. Drug Discov Today 2013;18: 163-172.

140 Rare diseases - Commission activities in the area of rare diseases. http://ec.europa.eu/ research/health/index.cfm?pg= area\&areaname $=$ rare (cited August 3,2018 ).

141 European Commission: Study on CrossBorder Cooperation - Capitalising on existing initiatives for cooperation in cross-border regions. https://ec.europa.eu/health/ sites/health/files/cross_border_care/ docs/2018_crossbordercooperation_frep_ en.pdf (cited August 3, 2018). 
142 Julkowska D, Austin CP, Cutillo CM, Gancberg D, Hager C, Halftermeyer J, et al: The importance of international collaboration for rare diseases research: a European perspective. Gene Ther 2017;24:562-571.

143 European Medicines Agency: Orphan incentives. http://www.ema.europa.eu/ema/ index.jsp?curl=pages/regulation/general/ general_content_000393.jsp\&mid= WC0b01ac058061f017 (cited August 3, 2018).

144 LAB-FAB-APP: Investing in the European future we want: Report of the independent High Level Group on maximising the impact of EU Research and Innovation Programmes. http://ec.europa.eu/research/ evaluations/pdf/archive/other_reports_ studies_and_documents/hlg_2017_report. pdf (cited July 28, 2018).
145 EU Budget for the Future: Research and Innovation 2021-2027. https://ec.europa.eu/ commission/sites/beta-political/files/budget-may2018-research-innovation_en.pdf (cited July 28, 2018).

146 Communication from the Commission to the European Parliament, the Council, the European Economic and Social Committee and the Committee of the Regions: Trade for All - Towards a more responsible trade and investment policy. https://eur-lex.europa. eu/legal-content/en/ALL/?uri=celex \% 3A52015DC0497 (cited July 28, 2018).
147 Allen B, Chan KK, Milne A: Basel III: is the cure worse than the disease? Int Rev Financ Anal 2012;25:159-166.

148 García-Cabrera AM, García-Soto MG, Durán-Herrera JJ: Opportunity motivation and SME internationalisation in emerging countries: evidence from entrepreneurs perception of institutions. Int Entrep Manag J 2016;12:879-910.

149 European Central Bank: Enhancing the Role of SMEs in Global Value Chains. https:// www.ecb.europa.eu/home/pdf/research/ compnet/Enhancing_the_role_of_SMEs. pdf?9235c9ba9b76a6a403bc10723d6dd11e (cited August 3, 2018). 